\title{
Cognitive Construction of the Official Discourse System in the Development of the National Central City of Xi'an*
}

\author{
Yanqin Cao \\ School of Humanities and International Education \\ Xi'an Peihua University, Chang'an Campus \\ Xi'an, China
}

\author{
Zhaohong Yao \\ School of Foreign Languages \\ Xidian University, Chang'an Campus \\ Xi'an, China
}

\begin{abstract}
With the proposal and implementation of "The Belt and Road" strategy, Xi'an has been an important node along The Silk Road and a national central city of China. The construction of its official discourse system plays a significant role in the publicity of political ideas, the formation of public psychology and the shaping of a positive and open city image. Based on the previous achievements of relevant official discourse studies both in China and foreign countries, this paper analyzes cognitive characteristics, the discourse framing model and the main principles in $\mathrm{Xi}$ 'an official discourse from the perspective of cognitive framing model and macroscopic framework of discourse analysis in social semiotics in order to create attractive and charismatic advise the official discourse, put forward proposals for creating attractive and charismatic official discourse, thus developing the official discourse system in line with the orientation and development of the city. Meanwhile, this paper is expected to enrich and promote the further development of related areas.
\end{abstract}

Keywords-official discourse system; cognitive features; the framing model; principles of construction

\section{INTRODUCTION}

The official discourse refers to the language used by official institutions or official figures on official occasions to express official will, which is a specific use of language that reveals specific purposes and is subject to a certain political culture [1]. Official discourse plays an important role in expressing political views, publicizing political ideas, forming orientation of public opinion and constructing public psychology. The research on official discourse by Chinese and foreign scholars has been conducted in many fields such as communication, culturology, semiotics, linguistics, sociology and economics. In the field of linguistics, it mainly focuses on the following aspects: analyzing political speeches and other official discourse from the perspective of critical discourse analysis to explore the ideology hidden in discourse [2] [3]; Political discourse translation strategy research represented by Jia Yuling [4] who has conducted a contrastive study of the original Chinese texts and its English

*Fund: This paper is the periodical achievements of $2019 \mathrm{Xi}$ 'an Social Science Planning Fund Project "Research on the Construction of Official Discourse System in the Development of Xi'an National Central City" with the project number of $19 \mathrm{Z} 61$. version in QiuShi from the perspective of discourse structure and discourse translation, thus constructing readable, understandable political discourse system for international communication based on improving the adaptability of the original and the coherent readability of the translated version, as well as the cognitive research on conceptual metaphors in political discourse, which is beneficial to understanding the ideology behind political discourse through metaphor, correctly interpreting the thoughts and viewpoints of politicians, and analyzing and solving political problems, so as to better serve the formulation of China's foreign policy and international exchange [5] [6] [7]. However, these studies rarely explain the thinking mechanism and cognitive operation of discourse creation and understanding in a deep level.

With the proposal and implementation of the national "One Belt and One Road" strategy, Xi'an has been an important node along The Silk Road and a national central city of China. The construction of its official discourse system plays a significant role in the publicity of political ideas, the formation of public psychology and the shaping of a positive and open city image.

Based on the previous achievements of relevant official discourse studies both at home and abroad, this study will analyze cognitive characteristics, the discourse framing model and the main principles in Xi'an official discourse from the perspective of cognitive framing model and macroscopic framework of discourse analysis in social semiotics in order to create attractive and charismatic advise the official discourse, in order to put forward proposals for creating attractive and charismatic official discourse, thus developing the official discourse system in line with the orientation and development of the city. Meanwhile, this paper is expected to enrich and promote the further development of related areas.

\section{THEORETICAL FRAMEWORK}

Lakoff, the founder of cognitive linguistics, establishes Framing Theory on the basis of the concept of frame proposed by American sociologist Goffman and linguist Fillmore. Lakoff [10] believes that audiences always use the frame, metaphor and other thinking blocks based on the body 
and the interaction between the body and the environment to understand discourse. Frame is usually represented by the main tools of our mental activities, such as metaphor, imagery, cultural stories and their neural connections to the emotional centers of the brain. Frame is also a kind of metaphorical thinking, which starts from narration and provides logic for our thinking and reasoning. It is dynamic, more appealing and more acceptable, and can be used to understand deep social ethical values [11]. Linguistic expressions activate frames and metaphors. Conceptual metaphors are generated when mappings are established between two frames through activated neural connections. Frames can be divided into surface frames and deep frames. The frames activated by linguistic expressions are surface frames, which mainly include metaphorical and nonmetaphorical surface frames. The expressions with metaphorical thinking can be classified as the metaphorical surface frames, and the moral system and world outlook activated by the surface frames can be classified as the deep frames. When the surface frames of discourse can activate the deep frames consistent with the values of the audience, the audience will be more likely to accept the discourse.

\section{COGNITIVE CHARACTERISTICS OF OFFICIAL DISCOURSE IN THE GRAND CITY OF XI'AN}

\section{A. Using Stories, Proverbs, Poems and Other Thinking Blocks}

Lakoff believes that political discourse must be carried out in the way of real reasoning. First, it must use frames, metaphors, stories, prototypes and so on as thinking blocks. Stories with narrative structure tend to win the support of the audience [12].

The speech given by Wang Yongkang, the former Secretary of the Central Committee of Xi'an under the leadership of the Communist Party of China, begins with "I long for one in all at the Royal City of Chang'an", which evokes the first sentence of the poem Endless Longing by the great poet $\mathrm{Li}$ Bai in the Tang Dynasty together with reminiscence and yearning for Chang'an. Through this celebrated poem, the speech increases the kindness, shortens the psychological distance to the business elites and entrepreneurs, and expresses the hospitality to people with lofty ideals from all walks of life in the construction of the national central city of Xi'an.

In this speech, the Municipal Secretary Wang Yongkang is also skillful at using warm-hearted stories with rich emotion to seize the audience. He shared the innovation story of Mr. Xu Xiaoping of Zhen Ge Fund, the entrepreneurial story of a couple along The Silk Road, the story of entrepreneurship and investment by Mr. Ni Zhengdong, chairman of QingKe Group, the story of investment in hard technology by Dr. Mi Lei in Xi'an Institute of Optics and Mechanics affiliated to the Chinese Academy of Sciences, the story of investment in new economy by Yi Dian World, the first unicorn company in Xi'an, and the story of investment in talent by Dr. Zhang Gang from London Business Institute. For example, in the story of entrepreneurship, a couple of lovers along The Silk Road -Mongolian young man Yuan Zhaohui and Kazakhstan beauty Anita were in romantic affairs through the Chang'an train bound for central Europe, and their business now is spread to Kazakhstan, Russia, which is a new "online silk road" connecting China and Central Asia. Audiences tend to accept stories with narrative structure, which are not only vivid in plot, but also more likely to arouse the associations of the audience, so as to obtain their active recognition of the opinions held by the speakers and play a good publicity effect. Secretary Wang Yongkang's speech tries to convey the message that Xi'an is becoming the best choice for entrepreneurs and investors to start their own business.

In his speech at the first Business Conference in Xi'an, Wang Yongkang used a couplet on the door of the temple of wealth in the Tang West Market: "benevolence is wealth, righteousness is honor; "Honesty is the ability to practice, faith is the ability to establish morality", the banner is "righteousness brings wealth" to vividly describe the spirit, code of conduct and ideology of the businessmen in Xi'an. This couplet shows that the gentleman loves money and takes money through honest means. This view of wealth based on character and conduct still affects the businessmen in Xi'an. The use of these proverbs and idioms are easy to read, and at the same time, it is easy for the audience to establish a psychological association based on the values generally respected by the society.

\section{B. Activating Conceptual Metaphors and Deep Frames by Surface Frames and Metaphorical Expressions}

Metaphorical expressions are ubiquitous in official discourse, which activate conceptual metaphors and the underlying deep frames.

Here is a piece of news in Xi'an Daily. All regions are intensifying efforts to build industrial layout and platforms around aviation and aerospace, in order to share the "cake" of the space economy. Here language expressions "intensifying efforts" and "cake", activate the conceptual metaphors "AVIATION AND AEROSPACE CAREER IS JOURNEY", "SPACE ECONOMY IS FOOD", conveying the message that at present there are a number of flourishing aerospace science and technology enterprises in China which have actively participated in commercial space development, joined the market competition, and China's commercial space has entered in the "golden age" of rapid development. At the same time, it also helps readers to obtain positive emotional experience. Only when all parties cooperate to make the cake bigger, can they enjoy more benefits. The cake frame activated by "cake" includes elements such as making a cake, dividing a cake, eating a cake, etc., and the relationship between the elements, as well as the scene of cake distribution. The mapping from "cake frame" to "space economy frame" forms the conceptual metaphor of "SPACE IS ECONOMY". When the space economy is in recession and the "cake" is not big enough, the contradiction in distribution in all aspects is more prominent. Then, one of the measures to solve the growth and distribution contradiction is to make the "cake" bigger, that is, to develop the space economy and increase social wealth. "Bigger cake" requires cooperation. The underlying structure is the collectivism of the Chinese nation. Xi'an Municipal 
Government hopes to provide policy support and cooperation platform for space enterprises to coordinate resources, innovate technologies and transform achievements depending on Xi'an National Civil Aerospace Industrial Base and Shaanxi National Aerospace Economic Technology Development Zone approved by the state.

Here is another piece of news from WeChat public platform "Xi'an Release": Making full use of local resource advantages of many college students, Xi'an implements the action plan that millions of college graduates are employed and start their business in Xi'an, improve supporting policies for college graduates' employment and entrepreneurship, optimize environment for employment and entrepreneurship, enhance the level of services for employment and entrepreneurship and attract more college graduates to focus on Xi'an, settle down in Xi'an, develop Xi'an, so it is more common for "the peacock to returns to its nest".

This news activates the conceptual metaphors of "GRADUATES ARE PEACOCKS" and "Xi'an IS HOME". The peacock, queen of all birds, is an auspicious bird. Since ancient times, the peacock has enjoyed a long reputation in art, legend, literature and religion, which is a symbol of good luck and happiness. It conveys the recognition of college graduates who are cherished to be peacocks by the Xi'an Municipal Government. It is hoped that they can choose to work and start their own businesses in Xi'an after graduation, give full play to their intelligence and wisdom, embrace the future with a sunny attitude, sweat youth, reap fruits of growth, and are actively engaged in the construction and development of Xi'an. Likewise, the conceptual metaphor "Xi'an IS HOME" is also activated. Xi'an Municipal Government has introduced a series of warm-hearted service and measures, such as College Graduates Employment Award and Award of Encouraging and Attracting College Graduates to Develop Their Career in Xi'an Conferred to Colleges and universities in Xi'an, social insurance subsidies, employment skills training, business subsidies, government subsidised loans, free entrepreneurial training, the entrepreneurial guidance services and all kinds of preferential policies, housing rent subsidies, etc. Meanwhile, the series of activities Pursuing Dream, Growing Flourishingly with Xi'an are actively held, including the six seasons of the New Year, the youth, graduation, the summer, back-to-school and the future, further establishing the identity of the "university city" and inspiring college students to love Xi'an, integrate into Xi'an, and devote themselves to the development of Xi'an. The activated deep frames are optimism and hard work consistent with the reader's values. In the long-term process of historical development, confronting whether prosperity or setbacks and difficulties, Chinese people always keep optimistic are persevering to overcome difficulties, which has already become ingrained in the spirit of the Chinese nation. Combined with the social and cultural context of accelerating the construction of national central city and being an important node city in "One Belt and One Road" strategy, it is not difficult for readers, especially college students, to understand the connotation of discourse. As an important force in the construction of Xi'an, enhanced college students will be more likely to develop empathy and emotional identification of Xi'an. We inspire young graduates to use their knowledge and wisdom to sow, grow and harvest in the best time of their lives.

Li Mingyuan, the newly-elected mayor, told reporters: "Xi'an has entered the fast track of high quality development", which activates the conceptual metaphor of "ECONOMIC DEVELOPMENT IS JOURNEY". The roads in the journey are important for the travelers to move forward; similarly the national, provincial policy support is an effective guarantee for the accelerated development of Xi'an. Nowadays, steady progress has been made in economic and social cultural undertakings, speeding up the construction of a national central city and the goal of building an international metropolis. The deep frames of positive striving and optimism are activated, which is in conformity with the positive life attitude preset in the public brain, and tend to obtain active recognition.

What follows is a piece of news in Xi'an Daily: "Practicing the spirit of craftsmen has become an important magic weapon in the transformation and upgrading of Shaanxi Blower Group Co., LTD." Not only senior managers but also grassroots staff in the company are upholding the cherished craftsman spirit, which activates the deep frame of win-win cooperation in line with the Chinese traditional moral mode of collectivism, speaking highly of the staff's spirit of down-to-earth and steady movement, who practice their eyesight, concentration, control, modestly consult the experienced staff and superiors to lay a solid foundation for their skills, Therefore, the market image of dedication, quality, concentration and innovation is established and widely recognized, which has set an example for other enterprises to further strengthen the persistence in the new era of development for the steady progress in the transformation and upgrading.

\section{Applying the Moral Model in Line with the Values of the Chinese Nation}

Wang Yongkang, the former Secretary of the Central Committee of Xi'an under the leadership of the Communist Party of China, delivered a speech on the graduation ceremony whose theme is "you are the forever care of Xi'an", reflecting the conceptual metaphor "Xi'an IS HOME". The construction of the theme is essentially based on the Chinese nation's deep-rooted sentiments that the country is like the home, which embodies the national tradition of loving, mutual aid, and empathy advocated by the moral values of the "kind parents' model".

Similarly, in the latest promotional video of "Xi'an Impression", an old man tells about the history of Xi'an with a little girl: "Xi'an is the spiritual home of the Chinese nation and the center of Chinese civilization", embodying the conceptual metaphor "THE COUNTRY IS HOME", in that a nation cannot live without the national spirit and the foundation of Chinese civilization has been deeply rooted in Xi'an, reflecting the Chinese nation's deeply ingrained patriotic values and moral model. 


\section{REFERENCES}

\section{THE FrAMing MODEL FOR POLITICAL DisCOURSE IN} XI'AN

Based on the above analysis, this paper tries to construct the framing model of the official discourse in Xi'an. Firstly, official discourse starts from the moral values, such as the traditional Chinese thought of "harmony", the concept of family responsibility of respecting and caring for brothers, the spirit of collectivism, and the core socialist values. Then, it follows the basic principles of tolerance and harmonious coexistence, explores the underlying deep frames in the discourse, such as "win-win and share" and "tolerance", and employs corresponding conceptual metaphors, such as "Xi'an IS HOME", "GRADUATES ARE FAMILY MEMEBERS", which are realized through concrete surface frames and metaphorical expressions, such as "journey of economic development" and "friendly city". All the expressions are in line with certain inference that Xi'an insists on mutually beneficial cooperation and win-win results. All expressions conform to certain narrative roles, that is, $\mathrm{Xi}^{\prime}$ an focuses on the overall development of mankind and seeks the greatest common ground of interests of all parties, and always insists on being brothers, friends and a community of common destiny with other cities and regions. The construction of Xi'an official discourse system based on this model is conducive to the transmission of the plan of "building a community with a shared future for mankind and realizing win-win and shared benefits", and highlights the international image of Xi'an as a metropolis with a sense of responsibility. Therefore, the framing model of Xi'an official discourse system can be summarized as follows: moral values $\rightarrow$ basic principles $\rightarrow$ deep frames and conceptual metaphors contained in the topic $\rightarrow$ surface frames and metaphorical expressions $\rightarrow$ inference $\rightarrow$ narrative role.

\section{CONCLUSION}

Focusing on the development of the national central city, the construction and dissemination of the official discourse in Xi'an must serve the city's development orientation and strategic mission. To develop friendly and cooperative relations with countries and regions along the new Silk Road Economic Belt, discourse should take the lead, especially official discourse which must play a leading role in exploring the features and stories of the friendly cooperation between Xi'an and the countries and regions along the Silk Road Economic Belt, making the voice of Xi'an, telling the cooperation stories as well to gain the recognition and support from the governments and people of the countries and regions along The Silk Road.

Based on the research in the field of cognitive frame theory and discourse analysis, this study analyzes the thinking blocks in the official discourse of Xi'an, such as stories, proverbs and poems, as well as the conceptual metaphors and surface and deep frames embodied therein. The study found that the expressions of official discourse reflect the harmonious moral values of the Chinese nation, and put forward the framing model of accurately positioning the role of cities under the "One Belt and One Road" strategy and the construction of official discourse system focusing on the strategic and interactive nature of discourse.
[1] Dou Weilin. A Comparative Study of Governmental Discourse between the People's Republic of China and the United States of America [D]. Shanghai International Studies University, 2011.

[2] Van Dijk. Discourse Studies: A Multidisciplinary Introduction [M]. London: Sage Publications, 2011.

[3] Dou Weilin. CDA of Intertextuality in Speeches of US-Sino Political Leader [J]. Foreign Languages and Their Teaching, 2009(11).

[4] Jia Yuling. On the Establishment and Translation of Foreign Political Discourse System - on the English Translation of Qiu Shi [J]. Chinese Translators Journal, 2017(03).

[5] Goatly, A. Washing the Brain: Metaphor and Hidden Ideology [M]. Amsterdam: John Benjamins, 2007.

[6] Wen Xu. Political Discourse and Political Metaphors [J]. Contemporary Foreign Languages Studies, 2014(09).

[7] Li Yu \& Zhan Quanwang. Analysis of Conceptual Metaphors in Chinese Political Discourse — exemplified by New Year's Day editorial in People's Daily [J]. Jiang-Huai Tribune, 2013(05).

[8] Goffman, E. Frame Analysis: an Essay on the Organization of Experience [M]. Cambridge: Harvard University Press, 1974.

[9] Fillmore, C. J. Frame Semantics [C]. Soeu: Hanshin, 1982.

[10] Lakoff, G. The Political Mind: Why You Can't Understand 21st Century Politics with an 18th Century Brain [M]. New York: Viking/Penguin, 2008.

[11] Wang Shaohua. A Metaphorical Aalysis of American Political Speeches - exemplified by Bush and Obama's Speeches [J]. Foreign Languages and Their Teaching,2011(04).

[12] Wang Shaohua. A Study on the Cognitive Construction of Chinese Political Discourse System : Exemplified by Xi Jinping's Two Speeches in Switzerland in 2017 [J]. Journal of Nanjing Normal University (Social Science Edition), 2017(05) 